\title{
PENERAPAN BIMBINGAN KELOMPOK DENGAN TEKNIK PEER GROUP UNTUK MENINGKATKAN KEMAMPUAN REMAJA DALAM MENJALIN PERSAHABATAN
}

\author{
Retno Tri Hariastuti \\ Program Studi Bimbingan Konseling Universitas Negeri Surabaya \\ e-mail: teetoet@yahoo.com.
}

\begin{abstract}
This study was conducted to examine the effectiveness of group guidance with peer group technique to improve friendship-making ability among adolescents who live in an orphanage institution. An experimental method with one group pre-test and post-test design was used. Forty young female teenagers who lived in Khoiriyah Hasyim orphanage institution in Surabaya were involved in the experiment. The subjects were chosen based on the pre-survey data collected using a questionnaire that shows the lack of their abilities in making friendship. Data were analysed using ttest. The result suggested that group guidance with peer group technique can improves adolescents' friendship-making ability in the context of orphanage environments.
\end{abstract}

Key words: friendship, group counseling, peer-group technique, teenagers, orphanage.

\begin{abstract}
Abstrak: Penelitian ini dilakukan untuk mengetahui efektivitas pengaruh bimbingan kelompok dengan teknik peer group untuk meningkatkan kemampuan menjalin persahabatan di kalangan remaja yang tinggal di sebuah yayasan panti asuhan. Metode eksperimen dengan desain pre-test dan post-test digunakan. Empat puluh remaja perempuan di panti asuhan Khoiriyah Hasyim Surabaya dilibatkan dalam eksperimen tersebut. Partisipan penelitian dipilih berdasarkan data pra-survei yang dikumpulkan melalui angket yang menunjukkan kurangnya kemampuan mereka dalam menjalin persahabatan dalam kelompok sebaya. Data dianalisis menggunakan t-test. Hasil penelitian menunjukkan bahwa kelompok bimbingan dengan teknik peer group dapat meningkatkan persahabatan kemampuan membuat remaja di lingkungan panti asuhan.
\end{abstract}

Kata kunci: Persahabatan, bimbingan kelompok, teknik peer group, remaja, panti asuhan.

Salah satu kegiatan yang dikembangkan individu pada masa remaja adalah menjalin interaksi dengan teman yang sebaya (Gander \& Gardiner, 1981). Remaja cenderung membentuk kelompok-kelompok sebaya yang mereka sebut dengan sahabat. Istilah persahabatan atau pertemanan menggambarkan perilaku kerjasama dan saling mendukung antara dua atau lebih entitas sosial. Ikatan persahabatan akan ditunjukkan oleh perilaku saling menolong di antara mereka, saling percaya, dan juga saling setia. Haber dan Runyon (1984) menyatakan bahwa persahabatan adalah hubungan interpersonal antar individu. Hubungan interpersonal yang efektif memerlukan individu-individu dengan karakteristik pribadi yang sehat dan seimbang. Perkembangan pribadi seseorang sebagian besar tergantung pada interaksi individu dengan individu lain melalui hubungan yang baik dan jujur, penuh rasa percaya, cita-cita dan komitmen bersama (Hurlock, 1992).

Tidak semua remaja tinggal di rumah bersama orang tuanya. Ada remaja yang tingal dipanti asuhan dikarenakan tidak memiliki keluarga yang utuh. Salah satu panti asuhan yang menaungi para remaja yaitu Panti Asuhan Khoiriyah Hasyim Surabaya. Beragam sebab yang membuat mereka tinggal di panti asuhan tersebut, antara lain, karena disorganisasi keluarga seperti perceraian kedua orang tua, krisis ekonomi keluarga atau meninggalnya salah satu bahkan kedua orang tua. Kondisi-kondisi keluarga tersebut bisa mengakibatkan remaja sebagai anggota 
keluarga kurang memiliki rasa percaya (trust) terhadap orang lain, kurang memiliki keterbukaan, serta kurang dapat mengembangkan rasa saling mendukung bersama orang lain dalam suatu interaksi sosial (Kahairuddin, 1985).

Panti asuhan Khoiriyah Hasyim Surabaya hanya memiliki seorang pengasuh untuk membina +50 anak. Sebagian besar anak yang diasuh di panti Khoiriyah Hasyim berusia remaja, yakni antara 13 sampai 18 tahun. Jumlah anak asuh yang tergolong remaja adalah 40 orang dari jumlah anak yang diasuh. Data awal yang diperoleh dari panti asuhan Khoiriyah Hasyim menunjukkan bahwa masih banyak remaja di panti asuhan tersebut yang menunjukkan perilaku individualistis. Kecenderungan mereka yang tampak menonjol yaitu melakukan kegiatan hanya didasarkan pada kebutuhannya sendiri. Para remaja tersebut tampaknya belum bisa saling percaya, mendukung atau terbuka satu sama lain. Hal ini terlihat dari aktivitas seharihari yang berhasil diamati, yaitu 20\% anak tidak mengetahui jika ada temannya yang sedang sakit, $15 \%$ anak membiarkan temannya kesulitan dalam mengerjakan PR, 10\% anak tak acuh bila temannya mengalami permasalahan di sekolah, dan $25 \%$ anak yang cenderung saling mengejek atau mengganggu temannya.

Selanjutnya usaha yang perlu dilakukan dalam rangka meningkatkan kemampuan remaja menjalin hubungan persahabatan tersebut adalah dengan mengoptimalisasikan berbagai layanan bimbingan kepada remaja. Salah satu bentuk kegiatannya dengan melakukan penerapan bimbingan kelompok dengan teknik peer group. Dalam kegiatan bimbingan kelompok dengan teknik peer group tersebut memungkinkan terjadinya interaksi dan muncul dinamika dalam kelompok yang akan membantu remaja untuk lebih terbuka dan menerima apa yang telah disepakati oleh kelompok. Dalam bimbingan kelompok dengan teknik peer group atau teman sebaya terdapat tahap-tahap yang mengandung usaha peningkatan kemampuan menjalin persahabatan pada remaja. Hal itu sesuai dengan apa yang dikemukakan oleh Prayitno (1998) bahwa yang dimaksud dengan bimbingan teman sebaya ialah bimbingan yang diberikan oleh remaja tertentu untuk membantu teman-teman sebayanya. Menurut Santosa (1999) penggunaan peer group ini dapat efektif untuk membantu interaksi antar teman dalam kelompok.

\section{METODE}

\section{Partisipan}

Empat puluh remaja putri dengan rentang usia 13 hingga 18 tahun yang tinggal di panti asuhan Khoiriyah Hasyim Surabaya dilibatkan dalam penelitian ini. Semua partisipan tersebut adalah perempuan. Data awal yang diperoleh melalui angket menunjukkan kecenderungan yang rendah dalam perilaku sosial mereka dalam berinteraksi dengan sesama teman dalam panti asuhan tersebut. Teknik pemilihan partisipan penelitian menggunakan purposive sampling, yakni partisipan yang memiliki skor rendah dalam kemampuan menjalin persahabatan ditetapkan menjadi subjek penelitian.

\section{Prosedur penelitian}

Penelitian ini dilakukan dengan pendekatan eksperimental dengan menggunakan pre-post test design. Partisipan penelitian memperoleh perlakuan berupa pemberian bimbingan kelompok dengan teknik peer group. Prosedur perlakuan bimbingan kelompok dengan teknik peer group dimulai dengan melakukan pre-test, yakni mengukur tingkat persahabatan dari subyek penelitian melalui angket persahabatan. Kemudian memberikan treatment (perlakuan) kepada subjek penelitian yang diawali dengan menentukan leader atau co-leader untuk masing-masing kelompok, yakni yang menunjukkan perilaku lebih bersahabat, baik berdasarkan pengamatan maupun hasil 
pengukuran lewat angket. Mereka ini yang akan menjadi motivator bagi teman-teman atau anggota kelompok. Masing-masing kelompok melakukan bimbingan kelompok dengan menggunakan teknik peer group, yakni teman sebaya yang menjadi pembimbing (leader). Setelah selesai perlakuan bimbingan kelompok dengan teknik peer group, lalu dilakukan post-test.

\section{Teknik analisis data}

Data penelitian dianalisis menggunakan t-test untuk sampel berpasangan. Teknik ini digunakan untuk melihat perbedaan skor antara pre test dan post test pada kelompok sampel penelitian yang sama.

\section{HASIL DAN PEMBAHASAN}

\section{Hasil}

Tingkat kemampuan menjalin hubungan persahabatan dapat diketahui dengan menetapkan kriteria kategorisasi berdasarkan letak mean hipotetik dan mean empiris subjek penelitian. Subjek akan dikelompokkan dalam lima kategori yaitu Sangat Tinggi, Tinggi, Sedang, Rendah, Sangat Rendah. Cara yang digunakan adalah menetapkan kriteria kategoris yang didasari oleh asumsi bahwa skor populasi subjek terdistribusi normal (Azwar, 2005).

Deskripsi data dalam penelitian ini adalah nilai minimal 40, nilai maksimal 160 , rerata 100 , dan standar deviasi 20 . Skor rerata yang diperoleh sebelum konseling adalah 83,90 dengan deviasi standar $(\sigma)$ sebesar 6,209 , sedangkan rerata setelah bimbingan kelompok sebesar 101,45 dengan deviasi standar $(\sigma)$ sebesar 6,072. Adapun rangkuman deskripsi data penelitian dapat dilihat pada tabel berikut:

Tabel 1. Deskripsi data

Descriptive Statistics

\begin{tabular}{|l|r|r|r|r|r|}
\hline & \multicolumn{1}{|c|}{ N } & \multicolumn{1}{c|}{ Mean } & Std. Deviation & Minimum & Maximum \\
\hline pre test & 40 & 83,90 & 6,209 & 73 & 103 \\
post test & 40 & 101,45 & 6,072 & 85 & 112 \\
\hline
\end{tabular}

Adapun kategorisasi skor subjek berdasarkan skor empirik dari data kemampuan remaja dalam menjalin hubungan persahabatan disajikan pada tabel berikut:

Tabel 2. Kategorisasi kemampuan remaja dalam menjalin hubungan persahabatan

\begin{tabular}{|c|c|c|c|c|c|}
\hline \multirow{2}{*}{ Kategori } & \multirow{2}{*}{$\begin{array}{l}\text { kemampuan } \\
\text { menjalin } \\
\text { persahabatan }\end{array}$} & \multicolumn{2}{|c|}{ Pre Test } & \multicolumn{2}{|c|}{ Post Test } \\
\hline & & $\mathrm{Jml}$ & $\%$ & $\mathrm{Jml}$ & $\%$ \\
\hline $\begin{array}{l}\text { Sangat } \\
\text { Rendah }\end{array}$ & (1) & 0 & 0 & 0 & 0 \\
\hline Rendah & $70 \quad x \leq 90$ & 34 & 85 & 0 & 0 \\
\hline Sedang & $90 \quad \mathrm{x} \leq 110$ & 6 & 15 & 37 & 92,5 \\
\hline Tinggi & $110 \quad x \leq 130$ & 0 & 0 & 3 & 7,5 \\
\hline $\begin{array}{l}\text { Sangat } \\
\text { Tinggi }\end{array}$ & $130<x$ & 0 & 0 & 0 & 0 \\
\hline
\end{tabular}

Kategorisasi menggunakan skor empirik, didasarkan pada distribusi normal yang dimiliki subjek penelitian. Adapun tujuan dari kategorisasi ini untuk melihat seberapa besar perubahan skor sebelum dan sesudah perlakuan. Dari hasil kategori, persentase subjek yang masuk pada kategori rendah dan sedang adalah $85 \%$ dan $15 \%$ pada pre test dan pada post test, persentase subjek yang masuk kategori rendah, sedang, dan tinggi adalah $0 \%, 92,5 \%$, dan 7,5\%. Hal ini menunjukkan bahwa ada perubahan yang signifikan pada saat pre dan post test, yaitu adanya peningkatan prosentase subjek yang memiliki skor rendah pada kemampuan remaja dalam menjalin hubungan persahabatan.

Hasil uji asumsi normalitas untuk pre test dan post test memiliki nilai KolmogorovSmirnov Z 0,663 dan 0,703 dengan $\mathrm{p}>0,05$. Hasil ini menunjukkan bahwa frekuensi dari semua kelompok memiliki sebaran normal. Berdasarkan analisis data melalui uji Levene's test, probabalitas $>0,05$, maka data kemampuan remaja menjalin hubungan persahabatan baik pre test maupun post test memiliki varian yang homogen, atau data berasal dari populasi-populasi dengan varian yang sama. Hasil uji perbedaan antara pre test dan post test sebagaimana ditunjukkan oleh tabel. 4 diperoleh hasil $\mathrm{t}=-23,081, \mathrm{p}=0,000(\mathrm{p}<0,05)$ yang berarti menunjukkan bahwa ada perbedaan yang signifikan dalam kemampuan 
remaja menjalin hubungan persahabatan antara sebelum dan sesudah diberikan bimbingan kelompok dengan teknik peer group. Adapun sumbangan efektif perlakuan yaitu Bimbingan Kelompok Dengan Teknik Peer group mampu meningkatkan kemampuan remaja dalam menjalin hubungan persahabatan $48 \%(\mathrm{R}$ Square $=0,48)$, sedangkan 64\% lainnya kemampuan remaja dalam menjalin hubungan persahabatan dipengaruhi oleh faktor-faktor lainnya.

\section{Pembahasan}

Hasil analisis ditemukan bahwa terdapat peningkatan kemampuan remaja menjalin hubungan persahabatan secara singkat signifikan antara sebelum diberi bimbingan kelompok dengan teknik peer group dan sesudah bimbingan kelompok dengan teknik peer group. Temuan diatas mendukung teori yang menyimpulkan bahwa bimbingan kelompok dengan teknik konseling peer group menunjukkan keefektifan dalam meningkatkan kemampuan remaja menjalin hubungan persahabatan (McGinnis, 1997). Hasil penelitian ini juga mendukung penelitian Shechtman dkk (2002) yang menghasilkan penemuan bahwa konseling kelompok pada remaja dapat meningkatkan tingkat kelekatan pada teman sebaya.

Bimbingan kelompok dengan teknik peer group efektif untuk meningkatkan kemampuan remaja menjalin hubungan persahabatan disebabkan oleh beberapa hal diantaranya; bimbingan kelompok dengan teknik peer group tersebut mudah dilaksanakan oleh remaja yang memiliki motivasi yang tinggi untuk membina relasi sosial yang lebih mendalam sehingga ia berharap akan mampu menjalin hubungan persahabatan serta peneliti memberi perlakuan bimbingan kelompok yang terbaik sehingga klien dapat berubah secara optimal. Tingkat persahabatan remaja sebelum mendapatkan layanan bimbingan kelompok dengan teknik peer group (pre-test), masih tergolong pada kategori sedang (S) dan rendah $(\mathrm{R})$, yang berarti bahwa persahabatan remaja masih cenderung negatif. Setelah mendapatkan layanan bimbingan kelompok dengan teknik peer group, tingkat persahabatan tergolong berada pada kategori Tinggi $(\mathrm{T})$, yang berarti bahwa persahabatan remaja sudah menunjukkan dan mengarah pada persahabatan yang positif. Hal ini menunjukkan bahwa dengan adanya layanan bimbingan kelompok dengan teknik peer group, mampu meningkatkan kemampuan menjalin hubungan persahabatan yang negatif ke arah peningkatan dan pengembangan persahabatan positif. Dengan demikian dapat disimpulkan bahwa persahabatan remaja sebelum mendapatkan layanan bimbingan kelompok dengan teknik peer group dengan sesudah mendapatkan layanan bimbingan kelompok dengan teknik peer group adalah berbeda dan mengalami peningkatan yang signifikan.

Setelah penerapan bimbingan kelompok dengan teknik peer group dilaksanakan remaja sudah tidak merasa malu-malu dalam berkomentar, bertanya ketika berdiskusi, dalam pelaksanaan layanan bimbingan kelompok mereka sudah bisa menjalankannya dengan baik walaupun belum begitu sempurna. Mereka sudah mulai menunjukkan rasa percaya terhadap dirinya, kejujuran, memberikan dukungan dan mengembangkan hubungan penuh arti pada orang lain. Melalui kegiatan layanan bimbingan kelompok dengan teknik peer group, anggota kelompok akan diajak untuk saling berinteraksi antar anggota kelompok dalam membahas, menyampaikan pertanyaan, pendapat, gagasan dan berdiskusi dalam kegiatan ini. Remaja juga dapat memanfaatkan dinamika kelompok dan interaksi interpersonal yang terjadi di dalam kelompok tersebut, yang dapat digunakan untuk memecahkan berbagai permasalahan remaja dan mereka akan berusaha belajar untuk meningkatkan kemampuan menjalin hubungan persahabatan.

Kegiatan bimbingan kelompok yang dilaksanakan dalam penelitian ini adalah bimbingan kelompok yang dilaksanakan 
dengan teknik peer group yang bertujuan untuk mengembangkan diri remaja secara utuh, karena kegiatan ini melibatkan pada semua aspek kemampuan remaja untuk bisa memunculkan potensi, keterampilan, pola pikir dan daya kreativitasnya, ketika mereka menjalankan peranannya dengan baik sebagai pemimpin maupun sebagai anggota dalam kegiatan bimbingan kelompok tersebut. Selain itu, dengan adanya pemanfaatan peer group untuk menjalankan kegiatan bimbingan kelompok ini, akan mendapatkan keleluasaan dalam berinteraksi dan memunculkan kehidupan kelompok yang interaktif dan dinamis serta menjalin hubungan yang lebih akrab dengan teman-teman sebayanya.

Hal itu sesuai dengan apa yang dikemukakan oleh Santosa (1999) yang menyebutkan bahwa peer group adalah kelompok teman anak sebaya yang sukses dimana ia dapat berinteraksi. Individu akan merasakan adanya kebersamaan didalam kelompok dan kesamaan satu dengan yang lainnya seperti dibidang usia, kebutuhan dan tujuan yang dapat memperkuat kelompok tersebut. Adanya unsur kesamaan tersebut remaja akan termotivasi oleh keberadaan teman yang lain dan berusaha menjadi sama atau setara dengan teman sebaya yang lain tersebut dengan melalui berbagai macam dukungan, saling berbagi pengalaman, berdiskusi dari hati ke hati (McGinnis, 1997). Dengan demikian mereka akan mendapatkan dukungan dan termotivasi melalui wadah peer group dan diskusi kelompok yang hangat, akrab, dinamis, interaktif dengan memberikan warna yang kompetitif secara positif dalam mencapai tujuan yang diinginkan, seperti kebutuhan untuk menyesuaikan diri, kebutuhan untuk bertukar pikiran, dan berbagi perasaan, kebutuhan menemukan nilai-nilai kehidupan sebagai pegangan dan kebutuhan untuk menjadi lebih mandiri, mengembangkan diri dan juga dalam meningkatkan kemampuan menjalin persahabatan.

Oleh karena itu, akan lebih efektif dan dinamis ketika individu tersebut dieratkan dalam suatu wadah yaitu kegiatan bimbingan kelompok berdiskusi secara kelompok ini dimana yang menjalankan dan berperan secara aktif adalah peer group itu sendiri. Bimbingan kelompok itu sendiri adalah merupakan salah satu bantuan yang diberikan kepada remaja dalam bentuk kegiatan kelompok yang bertujuan untuk dapat memecahkan berbagai persoalan remaja dan mengembangkan pribadi remaja. Melalui layanan bimbingan kelompok yang dilaksanakan dengan teknik peer group akan dapat memberikan pengenalan, pemahaman, dan pengembangan kepada remaja dalam menilai dirinya. Adanya bimbingan kelompok dengan teknik peer group, remaja akan menemukan jawaban dari pertanyaan yang muncul tentang diri mereka yang pada akhirnya mereka akan tahu dan memahami tentang dirinya.

\section{SIMPULAN}

Penelitian ini menyimpukan bahwa terdapat peningkatan kemampuan remaja dalam menjalin hubungan persahabatan secara sangat signifikan antara sebelum dan sesudah melakukan bimbingan kelompok dengan teknik peer group. Hal ini menunjukkan bahwa bimbingan kelompok dengan teknik peer group dapat diterapkan untuk meningkatkan kemmapuan remaja dalam menjalin hubungan persahabatan. Dengan demikian hipotesis penelitian dapat dibuktikan bahwa remaja mengalami peningkatan kemampuan menjalin hubungan persahabatan diantara teman-temannya.

\section{DAFTAR PUSTAKA}

Azwar, S. (2005). Penyusunan Skala Psikologi (Edisi I). Yogyakarta: Pustaka Pelajar Offset.
Gander, M.J \& Gardiner, H.W. (1981). Child and Adocescent Development. Boston: Brown \& Co. 
Haber A. \& Runyon, R.P. (1984). Psycology of Adjustment. Illnois: The Dorsey Press.

Hurlock, E.B. (1992). Psikologi Perkembangan, Suatu Pendekatan Sepanjang Kehidupan. Jakarta: Penerbit Erlangga.

Kahairuddin, H. (1985). Sosiologi Keluarga. Yogyakarta: Nur Cahya.

McGinnis, A.L. (1997). Faktor Dalam Persahabatan (Penerjemah Maria Irawati). Yayasan Media Buana Indonesia. Metanoia.
Prayitno. (1998). Konseling Pancawaskita. Padang: FIP UPI

Santosa, S. (1999). Dinamika Kelompok. Cet. ke II. Jakarta: Bumi Aksara

Shechtman, Z., Freidman, Y., Kashti, Y., and Sharabany, R. (2002). Group Counseling to Enhance Adolescents' Close Friendships. International Journal of Group Psychotherapy, 52 (4): 537-553. 